\title{
ICT부문 공적개발원조(ODA)의 효과성 제고방안
}

\author{
강 주 홍 국무총리실 개발협력기획과장
}

목 차
I. 서 론
II. ODA 이해 및 이론적 논의
III. 우리나라의 ICT부문 ODA 분석
IV. 주요 ICT ODA 사례 분석
V. 시사점 및 개선방안
VI. 결 론

\section{I. 서 론}

우리나라는 반세기만에 원조를 받던 수원국에서 탈피하여 원조를 주는 공여국으로 전환되었고 나 아가 선진 공여국간의 회의체인 $\mathrm{OECD} \mathrm{DAC(개발원조위원회)에} \mathrm{가입(2009년} \mathrm{11월)한} \mathrm{유일한} \mathrm{국가로}$ 서, 국내·외적으로 국제사회에 대한 기여를 확대해야 한다는 요청이 증대되고 있다.

원조도 공여국과 협력국간 주고 받는 활동인 만큼 협력국이 필요로 하는 분야에 지원하되, 공여국 이 갖고 있는 비교우위 분야에 집중하는 것이 유리하다. 우리나라는 '한강의 기적'이라고 일컬어지는 산업화와 압축성장에 성공한 데 이어, 정보화에도 크게 성공하였다. 정보화시대에 우리나라의 앞선 ICT(Information Communication Technology)부문은 다른 원조 분야보다 비교우위에 있고 이러한 이유로 ICT부문 ODA(Official Development Assistance)가 지속적으로 확대되는 추세에 있다.

최근에는 국제적으로도 ICT부문 ODA가 많은 관심을 끌고 있는데 이는 정보기술의 활용이 사회 전 반에 급속하게 확산되고 그 기반이 공고해짐에 따라 개도국의 변화와 발전에서 ICT의 적극적인 활용 이 불가피하기 때문이다. 2003년과 2005년에 걸쳐 개최된 「세계 정보사회 정상회의」(World Summit on Information Society : WSIS)는 정보사회와 관련된 제반 이슈를 포괄적으로 논의하였지만 그 가 운데 '국가간 정보격차 해소'를 핵심의제로 설정하고 개도국의 ICT역량 강화를 위한 국제협력 강화를 결의한 바 있다. 
$\mathrm{ICT}$ 부문 $\mathrm{ODA}$ 는 인프라, 의료 등 타 원조 분야와는 서로 다른 특징을 많이 갖고 있으므로 이를 감 안해야 개발효과성이 제고될 수 있다. ICT부문 $\mathrm{ODA}$ 는 선진국과 개도국간 정보격차 해소를 주요 목 적으로 하지만 기본적으로 인간의 커뮤니케이션 활동과 직접 연관된 것으로서 단순한 기술이전이 아 니다. 따라서 협력국의 사회 · 경제 · 문화적 여건 등을 충분히 고려하여야 하고 협력국의 발전상태를 고려한 단계적 지원이 필요하다. 아울러 ICT부문 ODA는 협력국의 기술표준 형성에 큰 영향을 줄 수 있으므로 향후 우리 기업의 진출 가능성도 같이 고려해야 한다.

그러나 실제 지금까지 이루어진 상당부문의 ICT분야 $\mathrm{ODA}$ 는 국가 차원의 전략이 부재한 상태에서 ICT부문의 특성도 충분히 고려되지 않은 채 여러 부처 - 기관들이 경쟁적으로 일회성 - 단기성 - 분절 화된 지원을 함으로써 ICT부문 $\mathrm{ODA}$ 의 효과성 - 효율성이 저해되었다. 이에 아래에서는 ICT부문 $\mathrm{ODA}$ 에 관한 이론적 논의를 살펴보고, 현황과 문제점 분석에 이어 개선방안을 모색하고자 한다.

본 연구는 문헌분석, $\mathrm{KOICA}$ (무상원조-한국국제협력단 : 외교통상부)와 $\mathrm{EDCF}$ (유상원조-대외경 제협력기금 : 기획재정부), 그리고 방통위, 행안부, 총리실 등 관련 부처의 자료 분석, 기타 인터넷자 료 분석 등을 통해 이루어졌다.

\section{ODA 이해 및 이론적 논의}

\section{1. $\mathrm{ODA}$ 의 개관}

공적개발원조(ODA : Official Development Assistance)란 OECD DAC1)(Development Assistance Committee)가 정한 수원국 리스트에 있는 국가 및 지역, 또는 다자간 개발협력기구에 제공되는 자금 또는 기술협력을 말한다. (OECD/DAC, 2001) 이에 따르면 공적개발원조는 (1) 중앙 및 지방정부, 그 집행기관 등의 공적기관에 의해 제공되어야 하며 (2) 개발도상국의 경제발전과 복지향상에 기여함을 주된 목적으로 해야 하고 (3) 공여조건이 완화된 원조, 즉 증여율(Grant Element)이 25\% 이상인 양 허성 조건의 자금이어야 한다.

통계 집계가 시작된 1961년 이래 2006년까지 OECD/DAC 회원국들은 약 1.6조 달러 상당의 원조를 집행했다. 1990년대에는 이른바 원조피로(Aid Fatigue) 현상과 금융위기의 여파로 인해 국제개발을 위한 원조가 감소하기도 했다. 그러나 2000년대 들어서 UN의 새천년개발목표2)와 2005년 원조의 효

1) $\mathrm{OECD}$ 의 23 개 전문위원회중 경제정책위원회, 무역위원회와 함께 3 대 위원회중의 하나임. 우리나라는 '09. 11월 동 위원회에 가입하였음

2) UN의 새천년개발목표(MDGs, Millennium Development Goals)) : 빈곤퇴치에 역점을 둔 2000년대 이후 국제사회 개발 협력에 있어 가장 중요한 최상위 목표이자 계획로서, '15년까지 달성할 8개 목표(1) 절대빈곤 및 기아퇴치 (2) 보편적 초등교육 달성 (3) 남녀평등 및 여성권익 향상 (4) 아동사망율 감소 (5) 모성보건 향상 (6) HIV/AIDS - 말라리아 및 각종 질병 퇴치 (7) 지속가능한 환경보전 (8) 개발을 위한 범지구적 파트너십 구축)를 측정 가능한 수치로 제시하였음 
과성 제고를 위한 파리선언3) 채택을 계기로 다시 증가세를 보이기 시작하여 2000년 및 2006년도 $\mathrm{OECD} / \mathrm{DAC}$ 공여국의 총 원조 규모는 각각 537 억불에서 1,044 억불로 두 배 가까이 늘어났다. (KOICA, 2009) 2010년 전체 DAC회원국의 ODA는 1,287억불로서 ODA/GNI는 0.32\%로 집계되었다.

최근 UN, OECD 등 국제사회에서는 원조규모의 확대(More Aid), 원조 효과성 제고(Better Aid), 글로벌 원조체제(Aid Architecture)의 변화에 큰 관심을 가지고 있다. 즉 원조규모를 늘리고 공여국 과 협력국의 파트너십으로 원조의 효과성을 높이며 다양한 원조주체들간 분절화(fragmentation) 방 지를 위해 조화와 협력을 추구하자는 것이 핵심요지이다.

세계화의 진전에 따라 상호의존성이 심화되고 국제협력이 증대하면서 선 · 후진국간 개발격차 문 제를 다루는 국제개발협력의 주체와 집행기관도 복잡 - 다기해지고 있다. 이렇듯 다양해진 개발 환경 에 부응하여 전통적인 개발원조위원회(DAC)의 공여국이나 유엔과 그 하부기관, 개발은행 뿐만 아니 라 DAC 비회원국, $\mathrm{NGO,} \mathrm{민간기업} \mathrm{등에} \mathrm{의해} \mathrm{개발원조의} \mathrm{활동영역도} \mathrm{확대되고} \mathrm{있다.}$

따라서 효율적인 국제개발협력을 위해 정부는 물론, 다자기구, 학계 및 전문기관, NGO 등을 포괄 하는 시민사회, 민간기업 등의 광범위한 연계와 협력이 필요해지고 있으며 이러한 ODA 환경의 변화 에 따라 $\mathrm{ODA}$ 의 추진과정에서 거버넌스 접근과 시각이 요구되고 있다. 한편, $\mathrm{ODA}$ 는 인도주의적 성 격 외에 외교정책의 수단이라는 측면을 지니고 있기 때문에 공여국들은 국익의 향상을 위해 부존자 원이 많거나 향후 시장수요가 큰 일부 협력국에 대해 소위 '총성 없는' 원조경쟁을 벌이고 있다.

우리나라는 1945 년 1999 년간 약 127 억불을 원조받아 이를 경제 - 사회 개발의 촉진제로 활용한 모범사례로 평가되고 있다. 우리나라는 원조를 받으면서도 1963년 USAID자금으로 개도국 초청연수 를 처음 시작하였고 1970 년대는 주로 북한과의 체제경쟁 등을 위해 주로 외교안보 차원에서 소규모 로 추진하다가 $\mathrm{EDCF}$ (1987년), $\mathrm{KOICA}(1991$ 년) 설립으로 대외원조의 기본틀을 갖춘 후 '90년대부터 대외원조를 본격화하였다.

2003년 이후 이라크와 아프간지원, 세계은행 · ADB 등 MDB(Multilateral Development Bank)에 의 출연 · 출자 증가 등으로 유·무상 예산이 2005 2011년간 연평균 $15.4 \%$ 늘어나면서 2 배 이상으 로 증가하였다. 그러나 EDCF가 설립된 1987년부터 2009년까지 총 원조규모는 약 69억불('09년 8.15 억불)로 우리나라가 받았던 수원액에 비해 여전히 적고 $\mathrm{ODA} / \mathrm{GNI}$ 비율도 $0.1 \%$ 에 불과해 $\mathrm{OECD}$ 의 2010년도 목표였던 GNI 대비 0.35\%와 비교해 보면 매우 낮은 수준이다. 또한 총규모 면에서도 DAC 회원국 23개국 중 19 위, GNI 비율과 1 인당 ODA규모는 최하위에 머물고 있다. (국무총리실, 2010)

3) 2005년 제2차 세계개발원조총회(HLF-2, 파리)에서 채택된 선언으로, 원조 효과성 제고를 위한 5 개 원칙을 제시하였음. 우리나라는 올해 11월말 부산에서 제4차 세계개발원조총회(HLF-4)를 개최할 예정임 
〈표 1〉ODA 예산의 연도별 추이

(단위:억원)

\begin{tabular}{|c|c|c|c|c|c|c|c|}
\hline 구 분 & 2005년 & 2006년 & 2007년 & 2008년 & 2009년 & 2010년 & 2011년 \\
\hline$\square$ ODA & 7,971 & 4,902 & 6,820 & 9,288 & 10,941 & 13,607 & 16,323 \\
\hline$(\mathrm{ODA} / \mathrm{GN} I, \%)$ & $(0.10)$ & $(0.05)$ & $(0.07)$ & $(0.09)$ & $(0.10)$ & $(0.12)$ & $(0.14)$ \\
\hline ○ 양자간 협력 & 4,943 & 3,835 & 4,910 & 6,208 & 8,034 & 10,024 & 12,177 \\
\hline - 무상원조 (KOICA 등) & 3,257 & 2,474 & 3,357 & 3,877 & 4,418 & 5,324 & 6,047 \\
\hline - 유상원조 (EDCF) & 1,686 & 1,361 & 1,553 & 2,331 & 3,616 & 4,700 & 6,130 \\
\hline 으다자간 협력 & 3,028 & 1,067 & 1,910 & 3,080 & 2,907 & 3,583 & 4,146 \\
\hline
\end{tabular}

한편 우리나라는 2009.11월 OECD DAC 가입시 'Special Review' 및 'DAC 실사보고서'에 $\mathrm{ODA} / \mathrm{GNI}$ 비율을 ' 12 년에는 $0.15 \%$ 로, ' 15 년에는 $0.25 \%$ 로 증가할 것을 공표한 바 있다. (OECD/DAC, 2009) 2010년 현재 우리나라는 전년대비 $25.7 \%$ 증가한 11.7 억불을 지원하여 ODA/GNI는 $0.12 \%$ ('09년 0.1\%)였다.

우리나라 원조의 가장 큰 특징은 추진체계가 다원화되어 있다는 것이다. 양자원조 중 무상은 외교 부와 30 여개 기관이, 유상은 기획재정부가 담당하고 있으며 다자원조 중 국제금융기구는 기획재정부 가, UN 등 기타기구는 외교부와 일반부처가 담당하고 있다. 이렇게 분산된 추진체계에서 원조사업 의 중복과 분절화는 피할 수 없는 현상이다4).(김은미 외, 2009)

2010 년 ODA 사업을 전수조사한 결과를 보면 약 1 조 3,600 억원의 재원을 가지고 32 개 기관이 160 여개 국가 - 국제기구에 1,070 여개 사업을 추진하는 것으로 나타났다. 또한 유상원조는 경제우선 정 책에 중점을 두는 반면, 무상원조는 인도주의적 혹은 포괄적 국익 우선 원조정책에 중점을 두어 이들 간에는 이견이 상당히 있다. 이에 2005년부터 국제개발협력위원회(위원장 : 국무총리)를 구성 · 운영 하고 있으며 작년초에 총리실에 무·유상 원조를 총괄 조정하는 조직을 신설한 바 있다.

\section{〈표 2〉ODA 담당기관 및 관련법 현황}

\begin{tabular}{l|l|l|l}
\hline \multicolumn{2}{c|}{ ODA 형태 } & \multicolumn{1}{c|}{ 담 당 기 관 } & \multicolumn{1}{c}{ 비 고 } \\
\hline \multirow{2}{*}{ 양자원조 } & 유상원조 & 기획재정부(EDCF) & 대외경제협력기금법 \\
\cline { 2 - 4 } & 무상원조 & 외교부(KOICA), 30개 기관 & 한국국제협력단법 등 \\
\hline \multirow{2}{*}{ 다자원조 } & 국제금융기구 & 기획재정부 & 국제금융기구가입조치법 \\
\cline { 2 - 4 } & 기타 국제기구 & 외교부 및 개별기관 & \\
\hline
\end{tabular}

자료 : 국무총리실, 2011

4) 이와 관련, 2008.3월 OECD DAC의 우리나라 ODA에 대한 특별검토시 원조 일관성 확보를 위해 원조수행기관 통합화 권고, 우리 정부 원조사업에 대한 정책 일관성 확보 및 $\mathrm{ODA}$ 국제규범(언타이드, 원조조화 등) 준수, 원조효과 제고를 위해 무상원조 수행체제 일원화 필요성 등이 제기되었음 


\section{ICT부문 ODA 선행연구 검토}

기술은 단지 하나의 물질적 도구 및 장비가 아니고, 기반(infrastructure)과 그것에 부수되는 요구 사항들(requirements), 기술적 기능 및 관리적 기능을 포괄하는 통합적인 것으로 이해되어야 한다. 여기에는 구체적 실체를 파악하기 힘든 사회적 및 문화적 요소인 가치, 규범 등도 포함된다. 또한 기 술의 영향은 그것이 도입되거나 영향을 미치려고 계획한 분야에만 그치지 않고 의도하지 않은 광범위 한 분야에까지 영향을 미칠 수 있고, 기술개발 및 이전 등 기술과 관련된 활동에는 다양한 이해 당사 자(stakeholder)가 관여한다. 따라서 기술 및 기술 이전을 이해하기 위해서는 통합적 시각(holistic)이 필요하다. (Hall, 1959)

위에서 살펴본 기술 일반의 세 가지 특성(물질적 및 사회·문화적 요소를 포함하는 포괄성, 영향의 광범위성, 이해관계의 다양성)은 정보기술에도 해당된다. 정보기술은 단지 하나의 기능을 수행하는 기술이 아니고, 대부분의 조직에 있어서 조직 운영의 기본 기술일 뿐 아니라, 조직을 더욱 효과적으 로 움직이게 하는 기술(enabling technology)로서 그 중요성이 점점 커지고 있다. 무엇보다도 정보 기술은 인간의 커뮤니케이션과 밀접한 관련을 갖는, 즉 인간의 커뮤니케이션을 지원하는 기술이다. 커뮤니케이션은 인간 활동의 본질적 측면이고, 다른 어떤 분야보다도 사회 - 문화적 요소가 결정적 영향을 미치고 있다. 결국 정보기술은 비실체적인 요소들과 더욱 밀접하게 상호작용하는 기술 체계 이다.(Liebenau and Backhouse, 1990)

정보기술과 사회시스템을 연구하는 학자들은 '정보시스템이란 사회시스템이며, 컴퓨터들의 조합으 로서의 컴퓨터시스템은 정보시스템의 한 구성 요소일 뿐이다' 라는 명제를 주장한다(Liebenau and Backhouse, 1990). 따라서 개발도상국으로의 정보기술의 이전에는 이런 사회시스템으로서의 정보시 스템의 특성을 고려하는 접근이 요구되고, 더욱 전문적인 접근이 필요하다(Walsham, Symons and Waema, 1990).

그러나 실제 ICT부문 ODA현장에서는 정보기술의 특수성이 충분히 고려되지 못하고 있는 것이 현 실이다. 이 때문에 정보기술 이전이 다른 일반기술의 이전보다 더 많은 문제점을 노정하고 있고, 개 도국에 대한 정보시스템 원조 프로젝트가 실패하는 경우가 더 많다는 지적도 있다(Heeks, 2002). 개 도국에 ICT를 지원하는 시도가 많이 실패하는 이유는 서구 선진국과 개도국이 서로 다른 문화와 사 회적 배경을 가지고 있기 때문에 나타나는 ICT 사업 디자인과 실제 적용간의 차이 때문이다. 정보기 술 이전 프로젝트에서 설계 - 개발자와 개도국의 사용자간의 사회 - 경제 · 문화적 거리가 상당히 멀 수가 있는데 이 경우 사용자들의 사회시스템을 간과한 정보 시스템이 이식될 가능성이 더 높다고 하 겠다.

또한 정보기술 그 자체가 목적이 되는 위험성도 있다. 정보기술은 여러 기능을 달성하게 하는 (Enabling) 기술 임에도 그것이 수행하고자 했던 원래 의도된 기능과는 별도로 소유 그 자체가 핵심 기능으로 잘못 인식되기도 한다. 최신 정보기술을 소유한다는 것 자체가 ‘현대성’의 상징으로 변질될 
수 있다. 이런 경향의 예는 협력국의 정보기술능력 특히 유지 · 보수 능력과 사회 · 문화적 요소들을 고려하지 않고서 첨단 정보기술로 가득 채워진 '정보접근센터' 설립 등에서 발견할 수 있다. 동시에 정보기술은 그 발전 속도가 빨라 노후화의 위험성이 아주 높다. 이런 빠른 노후화 위험성은 투자 및 도입 결정에 있어서 신중한 접근을 요구하는데 특히 개도국으로의 정보기술 이전에 있어서 대단히 중요한 고려 사항이다. 빠르게 진보하는 소프트웨어를 업데이트하는 데 필요한 비용, 그리고 그 소프 트웨어가 작동할 수 있는 하드웨어를 구비하는 데 드는 비용 등이 확보되지 않으면 기존에 투입된 자 원의 낭비를 가져온다. 이와 관련하여 자체적인 재원 마련 가능 여부와 함께 운영인력 등 관련 인력 양성 및 확보가 시급하다. 더구나 이렇게 개발되는 소프트웨어들이 위에서 언급한 바와 같이 현지의 사회 · 문화적 요구를 충족시키지도 못할 수 있다. 따라서 이상에서 살펴본 정보기술 이전의 문제점 들, 특히 정보기술의 사회시스템으로서의 특성으로 인해 정보기술의 이전에는 단지 기술요인 뿐만 아니라 사회 - 경제 문제 등 여러 요소를 통합적 시각을 갖춘 전문가 집단에 의한 프로젝트 수행이 요 구된다.

\section{ICT부문 ODA의 특성}

정보기술의 급속한 발전은 선진국과 개도국 사이에 정보격차(digital divide)를 낳으면서 기존의 개발격차를 더욱 가속화시키는 문제를 발생시키고 있다. 선진국에서는 중앙부처 업무의 전자화(전자 정부), 인터넷을 이용한 교육(e-러닝), 전자 상거래(e-커머스) 등 행정, 사회, 경제의 다양한 분야에 서 ICT가 활용되면서 경제사회 구조의 효율화, 생산성 향상, 생활의 질적 향상, 주민 서비스의 향상 등에 크게 기여하고 있다. 이에 반해, 개발도상국에서는 ICT를 이용하거나 배울 수도 없어 ICT의 혜 택을 받을 수 없는 실정이다. 이로 인해 ICT 이용가능 국가와 그렇지 못한 국가와의 정보격차 (Digital Divide)가 야기되고, 나아가 양자의 경제 격차를 더욱 확대시키게 된다. 그러나 국가간 정보 격차는 국내 정보격차 문제와 달리 격차문제의 해결을 위한 체계적인 대응체제 구축이 쉽지 않다. 왜 냐하면 국내 정보격차의 경우, 해당 국가의 법률이나 정부정책 집행 및 재정지원 등을 통해 완화될 수 있지만 국가간 정보격차의 경우에는 선진국 및 국제기구에게 정보화 후발국가에 대한 지원을 의 무화시킬 수는 없고 단지 자발적인 지원에 기대할 수밖에 없기 때문이다. ICT부문 ODA는 기본적으 로 정보통신 분야의 다양한 사업을 통해 선진국과 개도국간 정보격차 해소를 지원하는 데 주요 목적이 있다. 하지만 ICT 인프라 개선 지원을 통한 제도적 역량 강화 및 ICT 인적자원 개발 등을 통해 빈곤 완화, 경제·사회발전 토대를 구축하여 개도국의 경제성장에의 기여는 물론 새천년개발목표(MDGs) 관련 각종 목표 달성을 위한 기본 수단으로서도 매우 중요하다.

$\mathrm{ICT}$ 부문은 $\mathrm{ODA}$ 다른 분야에 여러 분야에 다각도로 접근할 수 있는 범분야(Cross-Cutting Issue) 이슈이고, 인프라 - 식량 - 의료 · 교육 · 자연재해 극복 등 다른 분야 개발협력과 성격이 상이하다. ICT부문은 기술, 제도적 요소들간 횡적 연계성이 강하며 정보화를 위해서는 공공부문 등 사회 특정 
분야의 노력만으로 이루어지는 것이 아니라 사회 전체가 참여하는 국가적 공감대가 형성되어야 한 다. 한편 ICT부문 $\mathrm{ODA}$ 에는 다수의 부처와 기관이 참여하기 때문에 공여국의 입장에서는 기존의 참 여기관과 관련 부처 - 단체간 긴밀한 협력체계를 구축할 필요가 있다. 한편 협력국의 입장에서는 ICT 지원후 이를 유지 · 보수할 수 있는 역량과 함께 통신, 네트워크의 구축 및 다양한 콘텐츠 제공을 위 한 정보통신서비스 사업자가 필요하다.

기존의 정보격차는 ICT에 대한 접근성이 중심적인 문제였으나 최근에는 ICT의 활용 문제가 더욱 부각되고 있으며, 또한 지금까지는 낮은 수준의 기술능력을 지닌 국가에 인프라와 하드웨어를 제공 하는 원조방식이 대다수를 차지하였으나 이제는 기술능력 구축처럼 하드웨어 및 소프트웨어를 통합 한 ICT 개발협력으로 관심이 전환되고 있다. (조정문, 2007)

이제 정보통신기술의 발전은 점차 경제, 사회, 문화 발전과 밀접해지면서 ICT 단독으로의 국제협 력활동에서 한 걸음 더 나아가 일반 산업 및 경제 기반으로써 다른 분야와 접목되어 ⿶ㅣㅇㄱ개도국 협력활 동으로 발전되고 있다. 예를 들면, 수자원개발 프로젝트에서도 정보기술은 여러 기계적 요소 및 기능 들의 조정 및 통제를 위한 본질적 요소가 되는 등 ICT는 일반 개발 프로젝트에도 필수불가결해지고 있다.

\section{ICT부문 ODA의 국내 - 외 현황}

개도국에 대한 ICT부문 ODA의 중요성으로 인해 선진국의 ICT부문 ODA가 증가하고 있기는 하지 만 교통인프라 - 식량 - 교육 등 전통적인 원조 경향의 관성으로 인해 DAC 회원국의 ODA에서 ICT부 문 ODA가 차지하는 규모는 대체로 작은 편이다. 미국의 경우 2.5 백만 3 백만달러 정도이고, 독일과 프랑스는 1.5 백만달러 정도, 오스트리아나 영국 등 대부분의 나라는 백만 달러 수준에도 못미치는 ICT 지원을 실시하고 있다. 일반적으로 각국 총 ODA에서 ICT원조가 차지하는 비중이 $0.1 \%$ 에도 미 치지 못하는 경우가 많다.

그러나 $\mathrm{DAC}$ 회원국 중 ICT 강국인 몇몇 나라의 경우 통신분야 ODA 집중도가 상대적으로 매우 높 아, 산업경쟁력의 수준이 ODA 구조에도 영향을 미치고 있음을 알 수 있다. ICT 강국으로 분류할 수 있는 한국, 일본, 네덜란드의 경우 절대적 규모에서나 상대적 비율에서 통신분야 ODA가 중요한 위치 를 차지하고 있다. 절대적 규모에서 ICT부문 ODA가 가장 큰 나라는 일본으로서, 2008년 2,400만 달 러에 이르고 있다. 그러나 ICT부문 ODA 비중이 가장 높은 나라는 우리나라로서, 2006 2008년 평 균 $7.6 \%$ 에 달해 다른 어떤 DAC 회원국에 비해 월등히 높은 비중을 보이고 있다.

하지만 ICT부문 ODA 규모의 대소와 관계없이 선진국의 ICT부문 ODA는 대부분 성공적이라는 평 가를 받고 있다. 일본과 미국을 중심으로 한 주요 ICT선진국들의 성공요인을 살펴보면 개도국의 정 보화 실정 및 수요를 파악하고 필요한 사업을 기획, 개발, 집행, 평가할 뿐만 아니라 ODA 참여국 정 부와 민간부문과의 유기적 협력 하에 사업이 추진되고 있다. 특히 사업집행시 정부 및 ODA 참여기관 
간 정보, 인력, 자원 등의 공유와 교류 등 유기적 협력과정이 나타나고 있다. 이처럼 사업추진 관련 기관간 협력과 파트너십의 제도화가 특징적이다. 그러나 외형적으로는 협력국의 경제성장과 발전을 추구하고 있지만 궁극적인 목표는 자국 산업의 수출 및 홍보 등의 기회로 활용하는 경향이 강하다. (권 율 외, 2008)

〈표 3〉DAC 주요 회원국의 통신분야 ODA 규모(2006 2008년)

\begin{tabular}{l|r|r|r|r}
\hline \multicolumn{1}{c|}{ 국 가 } & \multicolumn{1}{c|}{ (단위 : 백만달러) } \\
\hline Austria & 534.4 & 415.5 & 172.2 & $1,122.20$ \\
\hline- communications & 0.3 & 0.3 & 0.2 & 0.8 \\
\hline Belgium & 825.2 & 643.7 & 596.4 & $2,065.20$ \\
\hline- communications & 2.5 & 1.4 & 5.2 & 9 \\
\hline France & $4,618.30$ & $3,248.80$ & $3,113.80$ & $10,981.00$ \\
\hline- communications & 0.2 & 1.5 & 1.6 & 3.4 \\
\hline Germany & $3,518.70$ & $2,003.60$ & $2,906.00$ & $8,428.30$ \\
\hline- communications & 1.2 & 1.2 & 1.7 & 4 \\
\hline Japan & $3,478.80$ & $1,873.90$ & $1,075.70$ & $6,428.40$ \\
\hline- communications & 11.9 & 6.5 & 24.1 & 42.6 \\
\hline Korea & 40.9 & 54.7 & 88.1 & 183.7 \\
\hline- communications & 1.2 & 5.8 & 7 & 14 \\
\hline Netherlands & $1,322.80$ & $1,659.60$ & $1,445.70$ & $4,428.10$ \\
\hline- communications & 3.8 & 3.8 & 8.5 & 16.1 \\
\hline United Kingdom & $5,500.70$ & $2,684.00$ & $2,495.60$ & $10,680.40$ \\
\hline- communications & 0.4 & 0.3 & 0 & 0.7 \\
\hline United States & 3.6900 & $4,572.80$ & $6,875.00$ & $17,177.40$ \\
\hline- communications & 2.6 & 2.5 & 8.1 \\
\hline
\end{tabular}

자료 : OECD DAC, 2010

우리나라의 ICT부문 ODA 지원현황을 무·유상원조의 양대 축인 $\mathrm{KOICA}$ 와 $\mathrm{EDCF}$ 를 중심으로 살펴 보면 1990년대 초반만 해도 전체 ODA 사업 대비 ICT 비중은 평균 약 $3 \%$ 수준이었으나, 이후 지속적 으로 증가하여 2000 년대에는 $10 \%$ 내외의 수준에 이를 만큼 증가하였다.

먼저 무상원조인 KOICA의 지원 금액도 2004년 이후 큰 폭으로 증가하여 1991 2010년 기간 동안 지원 누계액은 약 2 조 7 천억원이고, 이중 정보통신분야는 2,683 억원으로 약 $10 \%$ 를 차지하고 있다. 
주요 지원 국가는 베트남, 몽골, 인도네시아, 이라크, 필리핀 등으로 이들 상위 5 개국에 대한 지원 비중이 $\mathrm{KOICA}$ 전체 ICT지원 금액의 $34 \%$ 를 차지하고 있다. $\mathrm{KOICA}$ 의 ICT부문 지원 사업형식은 프로 젝트 사업(60.0\%)과 해외봉사단 파견 사업(26.7\%)이 큰 비중을 차지하고 있다.

〈표 4〉 KOICA의 국가별 ICT부문 주요 사업 내역

\begin{tabular}{|c|c|c|c|}
\hline 사업 연도 & 국 가 & 사 업 명 & $\begin{array}{c}\mathrm{KOICA} \\
\text { 협력기관(PMC) }\end{array}$ \\
\hline $2006 \sim 2008$ & 과테말라 & 한-과테말라 ICT 교육센터 건립사업 & 동부 CNI \\
\hline $2006 \sim 2007$ & 라오스 & 라오스 외교부 전산망 구축 3차 사업 & 삼성네트웍스(주) \\
\hline \multirow[b]{2}{*}{$2004 \sim 2005$} & \multirow[b]{2}{*}{ 미얀마 } & 미얀마 정보통신정책 개발 마스터플랜 수립 지원사업 & \multirow{2}{*}{$\begin{array}{l}\text { 정보통신정책연구원 } \\
\text { (KISDI) }\end{array}$} \\
\hline & & $\begin{array}{l}: \text { 미얀마의 ICT 마스터플랜 및 세부 실행계획 수립으 } \\
\text { 로 개발격차 및 정보격차 완화 }\end{array}$ & \\
\hline \multirow[b]{2}{*}{$2006 \sim 2007$} & \multirow[b]{2}{*}{ 모로코 } & $\begin{array}{l}\text { 모로코 국립(알아카와인)대학 소프트웨어 개발센터 건립 } \\
\text { 사업 }\end{array}$ & \multirow{2}{*}{$\begin{array}{l}\text { (주)포스데이타 } \\
\text { (현. 포스쾨CT) }\end{array}$} \\
\hline & & $\begin{array}{l}\text { : 모로코 국립대학에 IT 교육 전문가 및 프로젝트 관리 } \\
\text { 전문가를 파견, IT 기반 교육 모델 공유와 인재육성을 } \\
\text { 통한 역량강화와 한국의 ICT 개발경험 공유 }\end{array}$ & \\
\hline \multirow[b]{2}{*}{2006} & \multirow[b]{2}{*}{ 몽골 } & 몽골 외무부 전자문서보관소 구축사업 & \multirow[b]{2}{*}{$\begin{array}{l}\text { (주)포스데이타 } \\
\text { (현 포스쾨CT) }\end{array}$} \\
\hline & & $\begin{array}{l}\text { : 몽골 외무부 산하 중앙외교문서보관소의 외교문서를 체 } \\
\text { 계적으로 관리할 수 있는 전자문서 보관소 구축 및 역량 } \\
\text { 강화 프로그램(국내초청연수 및 파견전문가의 현지 연수) }\end{array}$ & \\
\hline \multirow[b]{2}{*}{2001} & \multirow[b]{2}{*}{ 몽골 } & 몽골 IT Park 구축사업 & \\
\hline & & $\begin{array}{l}\text { : 몽골 수도 울란바타르의 중심가에 ICT 정보통신 창 } \\
\text { 업보육센터인 IT Park를 설립하고 대규모 네트워크 구축 } \\
\text { 및 운영을 통해 IT 기업발전 전략 자문, 역량강화 프로 } \\
\text { 그램 제공(매뉴얼 제작, 한국의 정보통신 개발경험 공유 } \\
\text { 현지 교육 및 국내초청연수) }\end{array}$ & SK C\&C \\
\hline $2006 \sim 2007$ & 방글라데시 & 한-방 교육분야 ICT 훈련원 건립지원사업 & LS전선(주) \\
\hline \multirow[b]{2}{*}{2006} & \multirow[b]{2}{*}{ 베트남 } & 베트남 호치민 정보아카데미 도서관 정보화 지원 사업 & \multirow[b]{2}{*}{ (주)다우데이터시스템 } \\
\hline & & $\begin{array}{l}\text { : 베트남 호치민 정치 아카데미 내 전자도서관 구축 } \\
\text { 및 역량강화 프로그램(국내초청연수 및 파견전문가의 현 } \\
\text { 지 연수) }\end{array}$ & \\
\hline $2006 \sim 2007$ & 우즈베키스탄 & 세계경제외교대 도서관 정보화 지원사업 & (주)다우데이터시스템 \\
\hline 2006 & 이라크 & 이라크(KRG) 아르빌 IT 훈련센터 건립사업 & 동부 $\mathrm{CNl}$ \\
\hline $2007 \sim 2008$ & 콩고민주공화국 & 콩고(DRC : 민주콩고) 4 개 정부부처 전산화를 위한 유 & (주)포스데이타 \\
\hline
\end{tabular}




\begin{tabular}{|c|c|c|c|}
\hline 사업 연도 & 국 가 & 사 업 명 & $\begin{array}{c}\text { KOICA } \\
\text { 협력기관(PMC) }\end{array}$ \\
\hline & & 선통신망 구축 & (현. 포스쾨CT) \\
\hline $2007 \sim 2008$ & 파나마 & 파나마 전자정부 및 원격교육 지원사업 & 삼성네트웍스(주) \\
\hline $2007 \sim 2008$ & 파라과이 & $\begin{array}{l}\text { 파라과이 중앙부처간 통신망 구축 및 정보체계 현대화 } \\
\text { 사업 }\end{array}$ & (주)케이티(KT) \\
\hline \multirow[b]{2}{*}{2006} & \multirow[b]{2}{*}{ 페루 } & 페루 국제협력청 IT 인프라 개선 & \multirow[b]{2}{*}{ 삼성네트웍스(주) } \\
\hline & & $\begin{array}{l}\text { : 페루 국제협력청에 전자문서 관리시스템 개발 및 화 } \\
\text { 상회의 시스템 구축 및 역량강화 프로그램(국내초청연수 } \\
\text { 및 파견전문가의 현지 연수) }\end{array}$ & \\
\hline $2007 \sim 2008$ & 페루 & 페루 국립공과대학 ICT 교육 역량강화 지원사업 & 삼성네트웍스(주) \\
\hline $2007 \sim 2008$ & 페루 & 페루 외교부 통합정보시스템 구축 지원사업 & 삼성네트웍스(주) \\
\hline
\end{tabular}

\section{〈그림 1〉KOICA의 부문별 지원 비중(1991 2010년)}

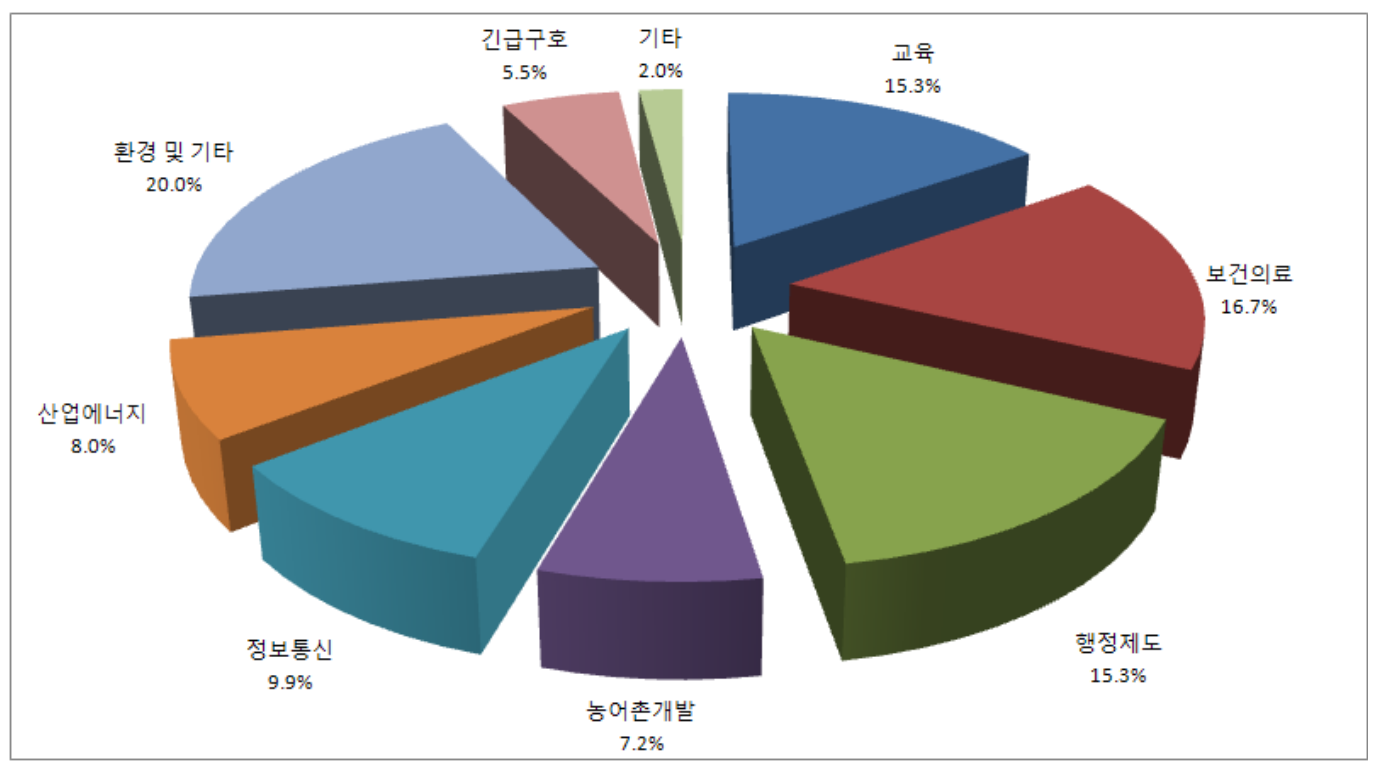

자료 : KOICA, 2011 
〈표 5〉KOICA의 ICT 부문 주요 지원 국가(1991 2010년)

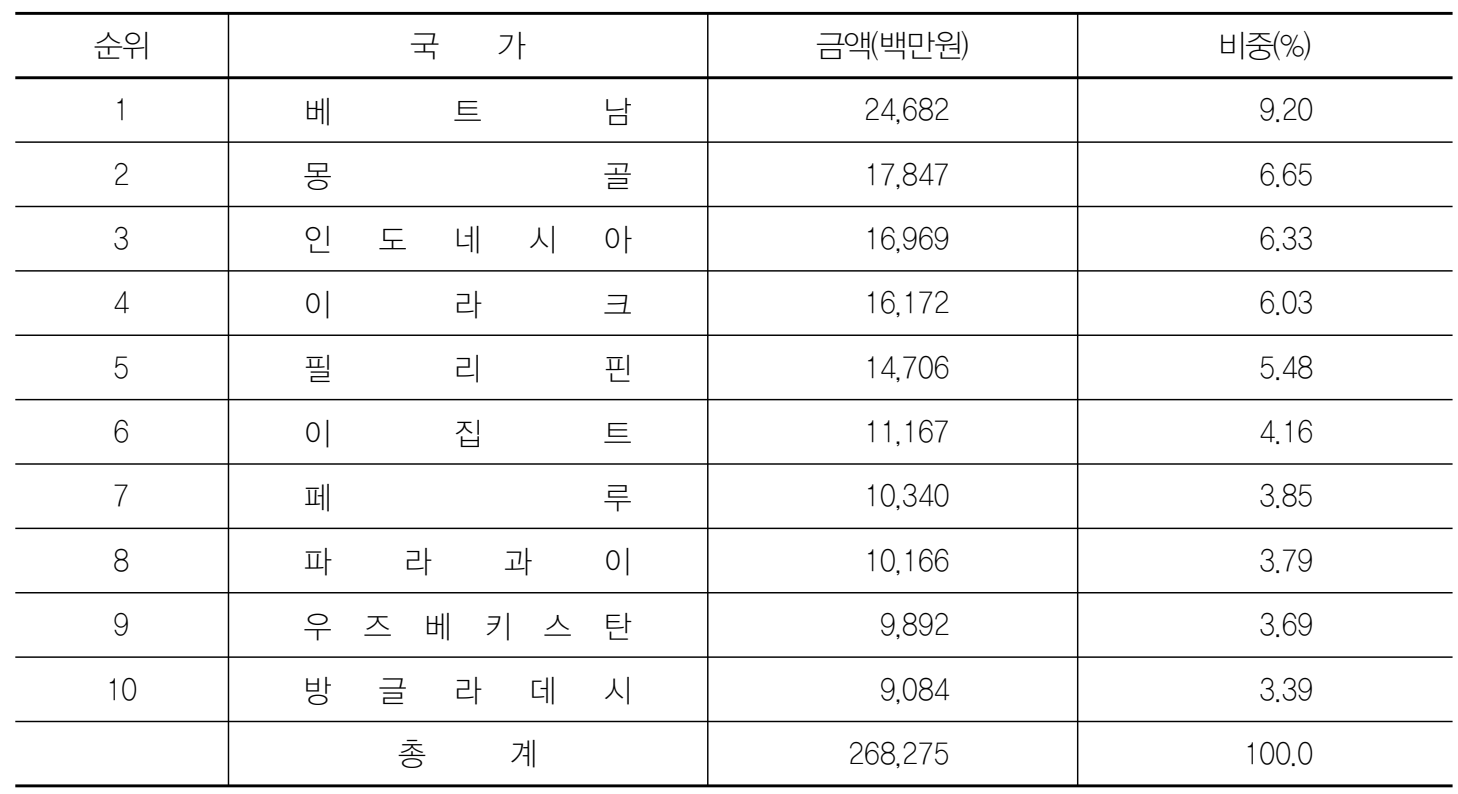

자료 : KOICA, 2011

〈표 6〉 KOICA의 ICT부문 형태별 지원 내역(1991 2010년)

\begin{tabular}{l|c|c|c}
\hline \multicolumn{1}{c|}{ 지원 형태 } & 지원 건수 & 금액(억원) & 비중(\%) \\
\hline 프로젝트 & 101건 & $1,608.8$ & 60.0 \\
\hline 물자지원 & 31 건 & 50.4 & 1.9 \\
\hline 개발조사 & 4 건 & 35.4 & 1.3 \\
\hline 연수생초청 & 235과정(3,593명) & 252.1 & 9.4 \\
\hline 전문가 & 89명 & 18.1 & 0.7 \\
\hline 해외봉사단 & 2,769명 & 716.4 & 26.7 \\
\hline 국제기구협력사업 & 1 건 & 1.2 & 0.04 \\
\hline \multicolumn{1}{c}{ 총 계 } & & 2,683 & 100.0 \\
\hline
\end{tabular}

자료 : KOICA, 2011

한편 유상원조인 $\mathrm{EDCF}$ 의 전체 지원 금액은 2006년 이후 큰 폭으로 증가하여 1987 2010년 기간 동안 지원 누계액은 약 7 조원이고 이중 ICT부문 지원 비중이 $14.4 \%$ 를 차지해 교통(35.7\%)분야, 수 자원 · 위생(16.1\%)에 이어 세 번째이다. 2000년이후에는 건별 지원 금액도 큰 폭으로 증가하여 1 건 당 320 억 350억원 규모에 이르고 있다. $\mathrm{EDCF}$ 의 ICT부문 지원 대상 지역은 동남아와 $\mathrm{CIS}$ 지역 등 아시아 국가와 일부 동유럽 국가에 집중되어 있으며 1990년 2010년간 ICT부문 ODA사업 건수는 총 
23 개국에 대해 45 건에 달한다.

\section{〈그림 2〉 EDCF의 부문별 지원 실적}

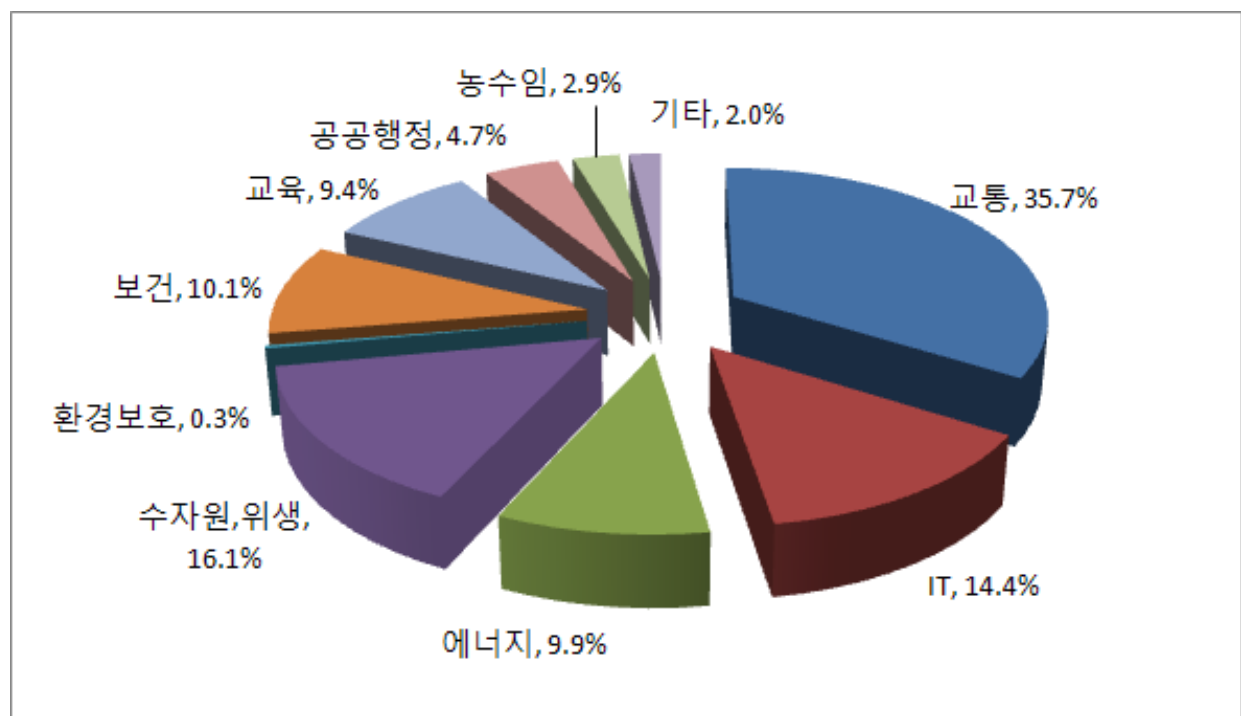

자료 : EDCF, 2011

〈표 7〉 EDCF의 국가별 ICT부문 사업 내역

\begin{tabular}{r|l|l|r|r}
\hline $\begin{array}{c}\text { 승인 } \\
\text { 연도 }\end{array}$ & \multicolumn{1}{|c|}{ 국가 } & \multicolumn{1}{|c|}{ 사 업 명 } & $\begin{array}{r}\text { 승인금액 } \\
\text { (백만원) }\end{array}$ & $\begin{array}{r}\text { 승인금액 } \\
\text { (백만불) }\end{array}$ \\
\hline 1990 & 필리핀 & 1차 전화망 확충 및 현대화 사업 & 3,790 & 5.38 \\
\hline 1991 & 우간다 & 지방전화망 확충사업 & 5,406 & 7.50 \\
\hline \multirow{2}{*}{1992} & 폴란드 & OPOLE주 통신망 현대화사업 & 38,173 & 50.00 \\
\cline { 2 - 5 } & 미얀마 & 전화통신망 확충사업 & 5,726 & 7.80 \\
\hline \multirow{2}{*}{1993} & 루마니아 & PRAHOVA주 통신망 현대화 사업 & 39,468 & 50.00 \\
\hline \multirow{2}{*}{1994} & 필리핀 & 2차 전화통신망 확충사업 & 8,249 & 10.20 \\
\hline \multirow{2}{*}{1995} & 에콰도르 & 지방통신망확충사업 & 11,467 & 15.00 \\
\cline { 2 - 5 } & 중국 & 호남성 통신망 확장사업 & 13,038 & 17.00 \\
\hline \multirow{2}{*}{1996} & \multirow{2}{*}{ 스리랑카 } & Horana 지방 전화망현대화 사업 & 11,725 & 15.00 \\
\cline { 2 - 5 } & 카자흐스탄 & 통신망 현대화사업 & 11,725 & 15.00 \\
\cline { 2 - 5 } & 우즈베키스탄 & 통신망 현대화사업 & 16,269 & 20.00 \\
\cline { 2 - 5 } & 루마니아 & ALBA주 및 주 통신망 현대화사업 & 12,486 & 15.00 \\
\hline \multirow{2}{*}{1998} & 키르기스스탄 & 통신망 현대화 사업 & 24,882 & 18.00 \\
\hline
\end{tabular}




\begin{tabular}{|c|c|c|c|c|}
\hline $\begin{array}{l}\text { 승인 } \\
\text { 연도 }\end{array}$ & 국가 & 사 업 명 & $\begin{array}{l}\text { 승인금액 } \\
\text { (백만원) }\end{array}$ & $\begin{array}{l}\text { 승인금액 } \\
\text { (백만불) }\end{array}$ \\
\hline \multirow{3}{*}{1999} & \multirow{2}{*}{ 몽골 } & 정부통신망 현대화사업 & 6,983 & 5.30 \\
\hline & & 지방통신망 확장사업 & 18,561 & 14.30 \\
\hline & 루마니아 & ALBA \& BUZAU 주 통신망 현대화 사업 PHASE ॥ & 16,538 & 13.00 \\
\hline \multirow{2}{*}{2001} & 방글라데시 & 통신망 현대화 사업 & 35,259 & 30.00 \\
\hline & 캄보디아 & 행정전산망 구축사업 & 26,350 & 20.00 \\
\hline 2003 & 예멘 & 통신망 확충 사업 & 32,075 & 30.00 \\
\hline \multirow{3}{*}{2004} & 인도네시아 & 국가범죄정보센터 개발사업 & 19,438 & 20.20 \\
\hline & 미얀마 & 전자정부 구축사업 & 12,794 & 12.50 \\
\hline & 스리랑카 & 전자정부 확충사업 & 14,534 & 15.00 \\
\hline \multirow{2}{*}{2005} & 도미니카공화국 & 관세시스템 전산화사업 & 22,108 & 23.00 \\
\hline & 방글라데시 & 인터넷정보망 확충사업 & 34,689 & 25.00 \\
\hline \multirow{7}{*}{2006} & 우즈베키스탄 & 교육정보화 사업 & 34,838 & 30.00 \\
\hline & 과테말라 & 교육정보화사업 & 27,049 & 23.60 \\
\hline & 인도네시아 & 바탐 전자정부 구축사업 & 14,747 & 16.00 \\
\hline & 몽골 & 울란바타르 지능형교통망 사업 & 17,327 & 12.80 \\
\hline & 캄보디아 & 지방행정정보망 확충사업 & 29,084 & 30.97 \\
\hline & 인도네시아 & 국가정보통신교육원 건립사업 & 19,362 & 21.00 \\
\hline & 앙골라 & 앙골라 국가정보처리센터 구축사업 & 33,193 & 35.00 \\
\hline \multirow{2}{*}{2007} & 세네갈 & 정부행정망 구축사업 & 26,003 & 25.00 \\
\hline & 베트남 & 디지털 방송 인프라 확충사업 & 28,853 & 25.00 \\
\hline \multirow{3}{*}{2008} & 방글라데시 & 해안통신국 현대화 및 해상조난안전시스템 구축사업 & 16,275 & 14.20 \\
\hline & 스리랑카 & 전자정부 확충사업(2차) & 8,331 & 6.65 \\
\hline & 방글라데시 & 국가정보통신망 개발사업 & 35,105 & 30.63 \\
\hline \multirow{5}{*}{2009} & 베트남 & 호치민 쭝릉 고속도로 지능형 교통시스템 구축사업 & 34,384 & 30.00 \\
\hline & \multirow{2}{*}{ 콜롬비아 } & 콜롬비아 ICT 교육역량강화사업 & 34,384 & 30.00 \\
\hline & & 콜롬비아 ICT R\&D 센터 건립사업 & 11,461 & 10.00 \\
\hline & 인도네시아 & 특허정보시스템 구축사업 & 37,823 & 33.00 \\
\hline & 방글라데시 & 방글라데시 ICT 교육훈련센터 건립사업 & 44,699 & 39.00 \\
\hline \multirow{3}{*}{2010} & 모잠비크 & 재난관리정보화시스템 확충사업 & 28,654 & 25.00 \\
\hline & 도미니카공화국 & 출입국관리시스템 구축사업 & 28,654 & 25.00 \\
\hline & 인도네시아 & 경찰청 무선통신망 구축사업 & 45,846 & 40.00 \\
\hline \multicolumn{3}{|r|}{ 합 계 (45건) } & $1,013,919$ & 969.00 \\
\hline
\end{tabular}

자료 : EDCF, 2011 


\section{III. 우리나라의 ICT부문 ODA 분석}

\section{ICT 발전과정 평가}

지금까지 우리나라는 전략분야를 단계별로 확정 - 제시하고, 정보화 수요와 전략산업의 육성 정책 을 종합 연계시키는 한편, 관련 추진체계 정비와 법적 기반을 확보하는 일련의 과정을 강력하게 추진 해 왔다. 기간별로 보면 70년대 후반 80년대까지 통신시설의 대량 확충과 현대화가 본격화 되었고, 80년대 후반 90년대 초반까지는 전산망을 국가기간산업으로서 네트워크화하고 반도체 기술개발, 전산자원의 공동 활용 등 정보사회를 위한 본격적 기반을 조성하였다. 이후 90 년대 후반부터 정부는 전산화단계에 머물렀던 정책체계를 근본적으로 재정비하여 정보화 추진체계, 비전·계획, 법·제도, 추진재원 등 범정부적 정보화역량을 모두 결집 - 추진하였고 그 결과, 우리나라는 21 세기에 들어서면 서 최고의 ICT강국으로 부상하여 세계가 주목하는 벤치마킹 대상이 되었다. (오정연, 2006)

이러한 ICT발전의 핵심적인 성공요인으로는 정보화를 통해 국가 경쟁력을 제고하고자 하는 국정 최고 책임자의 강력한 의지와 추진체계 확립(Leadership \& Institutional Arrangements), 미래 수 요를 예측하여 통신망을 고속 · 고도화하고 '선택과 집중'에 따라 ICT기술개발과 인력양성에 집중 투 자하는 전략분야 선택(Key Thrusts \& Development), 대규모 소요 투자의 확보 및 위험분산을 동시 에 달성한 투자재원조달 방식(Funding Mechanism) 등으로 분석되고 있다.

그러나 단기간 내 ICT 분야의 급속한 발전은 프라이버시 침해, 사이버테러 등 새로운 사회문제를 야기하기도 하였다. 이외에도 정보화가 심화되면서 방대한 정보가 무질서 - 무체계적으로 유통되면서 정보과잉 현상이 야기되었고, 정보 전달을 맡은 매체 발전을 비롯한 일반 과학기술의 발전 속도에 비 해 사람들의 적응력이 미처 따르지 못해 문화지체(Cultural Lag)현상도 뚜렷하게 나타나고 있다. 또 한 새로운 매체 기술과 뉴미디어 소유 격차에 의해 파생된 정보유통의 불평등 현상으로 인해 정보의 빈자(Information-Poor)와 정보의 부자(Information-Rich)간 지식격차(Knowledge-Gap) 문제도 발생하고 있다.

이외에도 ICT정책 추진과정에서 부처간 업무영역의 혼란과 갈등도 유발되었다. 정보화 사업은 통 신망 구축, $\mathrm{H} / \mathrm{W}$ 및 $\mathrm{S} / \mathrm{W}$ 산업 육성, 기술개발, 조직혁신 등 그 범위가 매우 넓어서 거의 전 부처의 영역에 걸쳐있기 때문에 단일 부처가 정보화 업무를 독점적으로 관장하기 어렵다. 뿐만 아니라 새로 운 기술이 끊임없이 출현하고 기술융합에 따라 새로운 업무 영역들이 계속 창출되기 때문에 기존의 업무분장 기준에 따라 관할 부처를 정하기가 매우 어렵게 되었다. 설사 업무 영역의 조정이 일시적으 로 이루어졌다고 하더라도 곧 이어 새로운 사업 분야들이 나타나기 때문에 부처간의 갈등관계가 지 속적으로 유지되고 있다. (김석주, 2010) 


\section{ICT부문 $\mathrm{ODA}$ 의 비교우위 분석}

통상 ODA는 다른 분야보다 비교우위 분야에 원조를 집중하는 것이 바람직하다. 우리나라의 경우, 정보통신 분야에서 세계적 수준의 우수한 IT기술과 충분한 IT전문 인력을 보유하고 있으며 민간 기 업은 물론 시민단체, 대학 및 연구소의 경험과 지식수준이 높다.(박복영, 2007)

우리나라 ICT부문에 대한 국제적 평가를 살펴보면 거의 최상위 순위를 유지하고 있다. 최근 기준 (2010년)으로 먼저 ITU의 ICT지수에서 총 159 개국 중 3 위를 차지하였고, UN의 전자정부 평가에서 는 1위를 차지하였다. 또한 $\mathrm{OECD}$ (2010년)에 따르면 인구 100 명당 무선초고속인터넷 가입건수 및 유 무선 초고속 인터넷 접속가구에 있어 세계 1 위이고, 커버리지 · 속도 등의 기타 지수에서 2 4위를 차지하였다. 또한 영국 옥스퍼드 대학 측이 조사한 초고속 인터넷 품질에 있어서는 2009년, 2010년 연속 세계 1위를 차지한 바 있다. (방송통신위원회 내부자료, 2011)

아울러 ICT산업 측면에서도 2010년 ICT산업의 수출과 무역흑자는 연간 사상 최대 실적을 기록하 였다. 2010년 ICT산업의 수출은 1,540 억불로 우리나라 전체 수출 4,674 억불의 $33 \%$ 를 차지하였고 전체 무역수지 흑자가 417억불임에 비해 ICT산업의 무역수지 흑자가 782 억불에 달해 ICT산업의 무 역수지 흑자를 제외하면 전체 무역수지가 오히려 365억불의 적자가 발생할 정도로 결정적인 역할을 하고 있다. 따라서 국제적으로 비교우위가 있는 ICT 분야에 특화하여 민간부문과의 연계 하에 정보 통신 기술 전수, ICT망 구축지원, ICT정책자문, ICT훈련센터 건립 등 개도국의 실질적인 정보격차 해소를 위한 지원활동에 역점을 둘 필요가 있다.

\section{ICT부문 ODA의 성과와 문제점}

ICT부문 ODA는 크게 ICT 초청연수사업, ICT 정책자문사업, ICT 인프라 지원사업 그리고 해외인 터넷봉사단 파견사업 등의 형태로 추진되고 있다.

개도국의 ICT역량을 강화하기 위해서는 우선 ICT를 주도하고 있는 주요 인적 자원의 개발 지원이 이루어져야 한다. 이에 우리나라는 개도국의 ICT 공무원 및 주요 업체의 임직원 등 개도국 ICT 정책 을 주도하는 이들의 교육 개발 지원을 위해 초청연수사업을 진행하고 있다. 1991년부터 2010년까지 총 117 개국으로부터 약 7,000 명(KOICA, 한국정보화진흥원 등의 실적 합계)을 초청연수시켰다. 이러 한 개도국 ICT인력 개발 지원은 개도국 ICT전문가의 역량배양 지원 뿐만 아니라 우리나라의 성공적 인 정책경험을 전수하고, 교육생들간 인적 네트워크를 구축함으로써 친한국적 ICT 환경이 조성되는 기반이 되고 있다.

우리나라는 정부주도의 성공적인 ICT 정책경험을 기반으로 세계적인 ICT 리더 국가로 자리매김을 할 수 있었다. 이러한 우리의 정책경험을 개도국과 공유하고 나아가 개도국에 적합한 정책방향을 제 시함으로써 개도국 ICT발전을 지원하기 위해 2000년대 초반부터 ICT정책자문 사업을 수행하여 왔 
다. 동 사업은 개도국에 국가정보화 정책, ICT 산업정책, ICT 법·제도, 정보보호 정책 등 개도국이 필요로 하는 자문 분야에 대해 우리나라의 성공적인 ICT정책경험을 기반으로 개도국의 ICT 정책방 향 및 추진전략 등에 관한 자문을 제공하는 것이다. 이러한 ICT정책자문은 개도국 ICT 발전 지원을 통한 국제정보격차 해소에 기여할 뿐만 아니라 한국형 ICT정책 경험을 전수, 전파함으로써 친한국적 ICT환경을 조성하는 데에도 기여하고 있다. 2002년부터 2006년까지는 주로 ASEAN의 개도국을 대 상으로 수행해 왔으며, 이러한 ICT정책자문 사업의 성공적인 결과를 바탕으로 2007년부터는 '공동번 영을 위한 개도국 정보통신 협력사업'으로 확대 발전함으로써 ASEAN 개도국뿐만 아니라 전 세계 개 도국을 대상으로 ICT정책자문 사업이 추진되게 되었다. 또한 2007년부터는 현황 분석 및 경험을 바 탕으로 정책방향을 제시하는 자문사업 외에 우리나라의 ICT정책을 직접 주도해 온 고위급 ICT전문 가를 개도국에 장기 파견하여 개도국의 ICT정책수행에 대한 상시자문활동을 하는 전문가 파견 사업 까지 진행되고 있다. 동 사업은 ICT정책자문을 통해 제시된 ICT정책 및 전략을 실행하기 위한 구체 적인 방법을 자문함으로써 보다 직접적으로 개도국의 ICT정책 활동을 지원하는 것이다.

또한 우리 정부는 개도국의 정보이용 환경을 개선하기 위한 지원활동도 활발히 수행해 왔다. 여기 에는 개도국에 정보접근센터 구축, 전자정부시스템 구축 등 ICT 인프라를 지원하는 사업과 ICT 전문 인력을 파견하여 ICT 교육 및 봉사활동을 전개하는 해외 인터넷봉사단 파견 사업이 있다. 먼저 개도 국 정보접근센터 구축사업은 개도국의 정보격차해소를 목적으로 개도국에 인터넷라운지, 정보화교육 장, 세미나실 등으로 구성된 한국형 ICT인프라를 구축하는 사업으로서 이를 통하여 개도국의 정보이 용기반을 조성함과 동시에 한국의 정보통신산업의 발전상 및 한국 정보문화의 우수성을 홍보하는 센 터로서 기능을 수행하고 있다. 이 사업은 지난 2002년 캄보디아에 정보접근센터 구축을 시작으로 2002년부터 2010년까지 총 26개국에 26개소의 정보접근센터를 구축 · 지원하여 왔다. 2003 2010 년까지 연인원 약 480 만명이 정보접근센터 시설을 이용한 것으로 추정된다. (한국정보화진흥원 내부 자료, 2011) ICT 인프라 지원사업에는 이외에도 앞서 살펴본 대로 $\mathrm{EDCF}$ 에서 총 45 건 사업에 약 1 조 원이 지원된 전자정부시스템 구축, 통신망 현대화사업 등이 있고 KOICA에서 총 101건 사업에 약 1,600 억원이 지원된 ICT훈련원 구축 사업 등이 있다.

해외 인터넷봉사단 파견 사업은 개도국의 정보격차 해소를 위해 대학생, ICT전문가 등 ICT인력을 정보화 후발국에 파견하여 약 1 개월간 현지 공무원, 지역주민을 대상으로 $\mathrm{PC}$ 일반교육 및 인터넷 활 용 등의 정보화 교육 및 관련 봉사활동을 수행함으로써 국제정보격차 해소에 기여하고, 글로벌 IT Korea의 이미지를 제고하는 사업이다. 2000년부터 2010년까지 총 68 개국에 약 5,000 여명이 파견되 어 활동하였다. 올해에는 20 여개국에 660 여명이 파견될 예정이다. (KOICA - NIA 내부자료, 2011)

그러나 $\mathrm{ICT}$ 부문 $\mathrm{ODA}$ 규모의 증가에도 불구하고 우리나라 $\mathrm{ODA}$ 의 전반적인 문제점과 마찬가지로 ICT부문 ODA도 비체계적이고 비효과적이라는 지적들이 꾸준히 제기되고 있다. 그 원인으로는 우선 $\mathrm{ICT}$ 부문 ODA정책의 이념 - 목표가 불명확하고 이에 따라 장기적 비전 · 전략이 미비한 점을 들 수 있 다. $\mathrm{KOICA}$ 는 분야별 중기전략을 수립하여 사업추진해 왔지만, 그간 우리의 ODA사업은 주어진 원조 
수단을 유기적으로 연계 - 활용하여 성과를 높이는 데 한계가 있었는데, 이는 특정 부문과 사업에 대 한 목표와 기대성과를 분명히 한 지원보다는 기자재 원조와 연수생 교육훈련 등 정형화된 지원을 그 때그때의 요구와 필요에 따라서 임의적으로 실시해 왔기 때문이다. (한국개발전략연구소, 2007)

또한 장기적 전략 부재 상태에서 ICT부문 ODA 담당기관간 정보교류 미흡, 분절화된 사업추진 등 으로 중복지원, 사업간 연계 미흡, 사후관리 부재 등의 문제점이 발생하고 있다.

\section{〈표 7〉ICT부문 ODA 관련 부처별 업무추진 현황}

\begin{tabular}{|c|c|c|c|}
\hline & 부 처 & 산하기관 & ICT 관련 주요 업무 \\
\hline 외교통상부 & $\begin{array}{l}\text { ODA(공적개발원조)/ } \\
\text { 전자정부 국제개발 } \\
\text { 협력 등 }\end{array}$ & KOICA & $\begin{array}{l}\text { - 개발도상국의 경제사회 발전 } \\
\text { - 개발도상국 빈곤퇴치 및 새천년개발목표 } \\
\text { (MDGs) 달성 지원 } \\
\text { - 정보화 마스터플랜 수립 } \\
\text { - ICT 창업보육센터 건립 및 실행방안 수립 } \\
\text { - 전자정부 구축 지원 } \\
\text { - ICT World Friends Korea 봉사단원 파견 } \\
\text { - ICT 직업훈련 역량강화 (IT훈련원 건립 및 } \\
\text { 교과과정 개선 등 컨설팅) } \\
\text { - ICT 전문가 국내초청연수 등 }\end{array}$ \\
\hline 행정안전부 & $\begin{array}{l}\text { 전자정부 } \\
\text { 국제협력 }\end{array}$ & $\begin{array}{l}\text { 한국정보화진흥원 } \\
\text { (N/A) }\end{array}$ & $\begin{array}{l}\text { - 정보화 전문기술 컨설팅 } \\
\text { - 정보화 국제컨설턴트 양성 } \\
\text { - ICT 협력센터, 정보접근센터 } \\
\text { - ICT 전문가 초청연수 } \\
\text { - ICT 청년봉사단 파견 등 }\end{array}$ \\
\hline \multirow{5}{*}{ 지식경제부 } & \multirow{5}{*}{$\begin{array}{l}\text { 전자정부 } \\
\text { 시스템 수출 }\end{array}$} & 정보통신산업진흥원(NIPA) & - 소프트웨어 수출지원 \\
\hline & & $\begin{array}{l}\text { 대한무역투자진흥공사 } \\
\text { (KOTRA) }\end{array}$ & - 기업 해외진출 지원 \\
\hline & & SW산업협회 & - 소프트웨어기업 수출지원 \\
\hline & & IT서비스산업협회 & - SI업체 수출 지원 \\
\hline & & 정보산업연합회 & - ICT기업 수출 지원 \\
\hline $\begin{array}{l}\text { 방송통신 } \\
\text { 위원회 }\end{array}$ & $\begin{array}{l}\text { 방송/통신 } \\
\text { 국제협력 }\end{array}$ & $\begin{array}{l}\text { 한국인터넷진흥원 } \\
\text { (KISA) }\end{array}$ & $\begin{array}{l}\text { - 방송통신 해외홍보 및 CONEX 운영 } \\
\text { - 해외 방송통신 전문가 초청 } \\
\text { - 방송통신 해외 로드쇼, 및 글로벌 마케팅 } \\
\text { - 방송통신 분야 정부 간 컨설팅 제공 }\end{array}$ \\
\hline 기획재정부 & 대외협력기금 & 수출입은행 & - EDCF 기금관리 \\
\hline
\end{tabular}

자료 : 한국국제협력단 및 한국정보화진흥원, 2010 
사업 선정의 경우 지금까지는 수요자인 협력국의 입장보다 공급자적 시각에서 이루어진 경향이 있 고 각 단위 사업들 간의 연계가 미흡하여 개별 - 단기사업 중심으로 사업이 선정되어 추진되어 왔다. 사업 구성면에서도 대체로 2 5년을 사업기간으로 하는 장기 프로젝트는 소수에 그치고, 대부분 1년 이 안 되는, 경우에 따라서는 2 3개월의 단기사업 중심으로 이루어져 왔다. 이는 대부분의 공여국 이 기술 컨설팅 중심의 사업 발굴 및 수행을 할 때 생기는 일반적인 문제점이기도 하다. 이처럼 단기 적 시각에서 이루어지는 개발협력 사업 추진으로 인해 전반적인 개발의 목표, 주요 정책 과제, 투자 우선순위 등에 입각한 유망 사업을 발굴하는 데 한계가 있었다.

이처럼 우리나라 ICT산업의 전체적인 맥락을 고려한 종합적 시각에서 협력국 선정이 이루어지기 보다는 기관 및 부처별로, 때로는 막연하고 모호한 기준에 따라 협력국 선정이 이루어지다 보니 협력 국에서의 중장기적 성과를 확인하기도 어려웠다. 결국 기존의 ICT ODA는 폭넓은 분야에 비교적 다 양한 유형의 사업이 추진되었지만 이를 바탕으로 개도국의 정보기술능력 향상이나 사회 개선 등의 목표를 달성하는 데는 제한적이었다. 또한 현재 진행되는 ICT ODA 사업들은 기초 수준의 사업들이 소규모, 산발적으로 진행됨으로써 되어 표준을 통한 정보통신산업의 세계 시장 진출이라는 전략과 유리되어 있었고, 이 사업들이 국내 정보통신산업에 미치는 연결 고리를 찾기가 어려웠다.

\section{IV. 주요 ICT ODA 사례 분석}

OECD DAC(1991년)에서는 ODA사업에 대해 적합성, 효과성, 효율성, 영향력, 지속가능성 등 5 대 기준을 적용하여 평가를 실시할 것을 권고하고 있다. 각각의 기준을 ICT부문 ODA에 적용하면 적합 성 기준은 ICT 지원이 협력국 개발환경 및 수요 등에 대한 부합하는지 그리고 ICT 지원사업이 협력 국의 경제·사회적 조건 등을 고려하여 적절하게 수행되는지 등을 의미하며, 효과성 기준은 ICT 지 원사업의 목적 - 성과 달성 여부 및 달성 정도 등을 의미하고, 효율성 기준은 ICT 지원사업이 예산 대 비 효율적인지 그리고 사업 추진체계와 절차 등이 효율적인지 등을 의미한다. 영향력 평가는 ICT 지 원사업의 긍정적 - 부정적 파급효과와 협력국 관련기관의 역량개발, 제도강화, 인재 육성, 생활 개선 등에 기여하였는지 등을 의미하며, 지속가능성 평가는 ICT 지원사업의 성과가 일회성에 그치지 않고 지속적으로 영향을 미치는지 그리고 관련 시설 - 인재 육성과 후임자를 위한 교육 시스템 등이 지속 적으로 업데이트되고 있는지 등을 의미한다.

ICT ODA사업의 성과 분석에 있어서 공여국의 입장에서는 적합성, 효과성, 효율성이 상대적으로 더 중요하고 협력국의 입장에서는 영향력, 지속가능성이 상대적으로 더 중요하다. 아래에서는 적합 성 실패사례와 효과성 · 효율성과 직결된 ODA사업간 중복 · 연계 미흡사례, 그리고 영향력·지속 가 능성과 직결된 협력국의 의지 · 협력 성공 사례를 분석하고자 한다. 


\section{1. 지원의 적합성 실패 사례}

협력국에 시설건축, 물품지원 등의 무·유상 원조를 할 때에는 사업목적 및 범위, 협력국의 경제 · 사회 발전 정도 등을 고려하여 현지 실정에 적합하게 지원하고 지원물품 등이 원활하게 사용될 수 있 도록 충분한 운영교육을 실시해야 한다.

감사원의 자료(2011년)에 따르면 KOICA에서 2004년 3월 필리핀에 '한 · 필리핀 IT훈련원 건립사 업'(사업기간 : 2004 2005, 총사업비 : 500만달러)을 추진하기로 하고, 퀘존 IT훈련원에 430만달 러, 블라칸 IT훈련원에 70 만달러를 지원하였는데 교육수요 등 현지 여건에 맞는 교과과정 및 적정 규모에 등에 대한 면밀한 검토없이 퀘존 IT훈련원을 대규모(건축연면적 $3,000 \mathrm{~m}^{2}$ )로 건립하도록 지원 하였다5). 그 결과 2005.12월 동 훈련원을 개원한 뒤 이듬해 6월부터 교육생을 모집하여 운영하고 있 으나 2006년부터 2009년까지 2D 및 3D 애니메이션 등 3 4개 과정만 운영하는 등 당초 10 개 과정 의 다양한 IT 고급기술자를 양성하려던 계획과 다르게 운영하다가 2010년 1월부터는 아예 수강생이 없어 교육과정이 개설되지 못해 훈련원 건물의 일부를 인근 대학에 강의실(7개)과 도서관으로 임대 하고 있다. 또한 동 훈련원이 큰 건물이어서 청소원, 경비원 등 많은 직원들이 종사함으로써 이들에 대한 인건비가 많이 소요되고 위 사업을 추진하면서 국내 초청연수를 받았던 운영자들이 동 훈련원 의 강사로 재직하지 않고 이직해버려 외부강사를 초빙하는 등의 비용들이 추가로 학생들의 수업료에 반영됨으로써 훈련생들이 등록을 기피하는 원인으로 작용하고 있다. 이에 비해 두 훈련원중 소규모

5) 필리핀 내 IT분야의 급격한 성장세 및 관련분야 대학생 수가 전체 대학생의 $11.5 \%$ 에 이르는 등 ICT 산업기반을 감안, 졸업생의 취업 문제에 대한 고려에서 비롯된 것이며, 퀘손 IT훈련원이 위치한 필리핀 기술전문대학 영내에 ICT관련 수 업이 일반적인 워드프로세서 등 사무자동화 수준이었기 때문이기도 하다. 이를 한 단계 높일 수 있는 방향으로의 사업 지원이 필요한 상황에서 일본의 국제개발협력기관인 JICA(일본 국제협력기구) 또한 IT Park구축(1.5억 달러), 필리핀 국립대 IT센터건립(2.1천 만 달러)을 통해 첨단 IT산업에 필요한 인재양성을 목적으로 지원하는 등 고급인력 양성에 대 한 필요성은 필리핀 내 IT분야 지원에 있어 원조공여국의 공통된 주요 관심사였다. 위와 같은 검토 결과 KOICA는 고급 IT기술인력 양성을 목표로 전문훈련원을 건립하는 것이 타당하다고 판단하여, 센터의 규모측면에서 동 사업이 우리 정 부의 약속에 따라 추진된 상징성을 고려해 지원하였다. 한편 불라칸 ICT 훈련원은 신축이 아닌 기존 훈련원을 개보수함 에 따라 사업비 소요가 축소된점을 고려 잔여예산을 퀘손 훈련원 신축에 활용하도록 계획을 수립했으며, 필리핀 정부에 대한 정부간 약속에 따라 지원금액 또한 정해진 상황이었기에 소규모로 지원보다는 랜드마크 성격의 지원이 포함되는 것을 필리핀 정부와 협의를 통해 결론을 도출하였다. 그 결과 2005.12월 동 훈련원을 개원한 뒤 이듬해 6월부터 교육 생을 모집하여 운영하고 있으나 2006년부터 2009년까지 2D 및 3D 애니메이션 등 3 4개 과정만 운영하는 등 당초 10 개 과정의 다양한 IT 고급기술자를 양성하려던 계획과 다르게 운영하다가 2010년 1월부터는 아예 수강생이 없어 교육 과정이 개설되지 못해 훈련원 건물의 일부를 인근 대학에 강의실(7개)과 도서관으로 임대했다. 그러나 한국국제협력단 과 필리핀 TESDA(기술교육개발청)는 대통령 장학금을 유치하여, 수강생들에게 장학금을 제공하였고, KOICA ICT 전문 가로 구성된 시니어 봉사단원과 단원 3 명 이상이 상주하면서 고급 인재 양성에 기여했다. 또한, 각 대학의 여름학기 컴 퓨터 강좌와 현장학습(OJT)을 유치하여 훈련원의 인건비 소요에 부응했다. 불라칸 IT훈련원의 경우 콜센터 교육 과정 등 교육수요에 적합한 새 강의과목을 개설하는 등 적극적인 경영으로 현재까지도 잘 운영되고 있다. 국제협력단은 필리 핀 정부가 보는 IT분야의 중요성과 아로요 대통령의 요청이 바탕이 된 개발수요를 중심으로 지원하는 것이 사업효과성 및 협력국의 Ownership을 제고 측면에서 더 효과적이라고 판단하여 IT전문훈련원 건립사업을 추진했다. 사후 운영은 수원기관의 자체 예산부담 등 운영역량이 가장 중요한 문제로 준공식 이후 운영권한 전권을 이양받은 필리핀 정부는 원 활한 훈련원 운영을 위해 기존의 운영주체였던 기술교육개발청(TESDA)에서 퀘손 시 정부로 운영주체를 바꿨다. 퀘손 이 정부청사 등이 집중되어 있는 행정 중심지이며, 필리핀 국립대학교, 아테네오 대학교 등 명문대학교의 본교가 모여 있는 대학가라는 점을 감안한 결정이었다. 또한 필리핀 교육행정 체계상 기술교육훈련을 담당하는 TESDA가 운영을 지 원하여 2009년 이후 운영에 개선에 노력하고 있다. 
로 건립한 블라칸 IT훈련원의 경우 교육수요에 적합하여 현재까지도 잘 운영되고 있다.

\section{2. 사업 중복·연계 미흡 사례}

각 부처에서 상호 연계 없이 ICT부문 ODA 사업을 개별적으로 추진하는 과정에서 유사 - 중복사업 들이 발생하여 자원 - 예산 낭비가 초래되거나 자원의 초과배분 등의 문제가 야기되고 있다. 예를 들 면 다음의 표에서 보듯이 베트남의 ICT부문에 여러 기관의 원조가 중복됨으로써 사업간 연계 및 시 너지 효과를 거두기 어려웠다. (감사원, 2011)

〈표 8〉베트남에 대한 ICT부문 중복지원 현황(2007 2009년)

\begin{tabular}{|c|c|c|}
\hline 공여기관명 & 지원사업명 & 지출액(만 달러) \\
\hline \multirow{3}{*}{$\begin{array}{l}\text { 한국국제협력단 } \\
\text { (KOICA) }\end{array}$} & 호치민 정치아카데미 전자도서관 & 49.2 \\
\hline & 한 · 베트남 친선 IT대학 & 49.0 \\
\hline & 베트남 IT 감사세미나 등 ITR관련 연수사업 & 62.3 \\
\hline \multirow{2}{*}{$\begin{array}{c}\text { 지식경제부 } \\
\text { (구 산업자원부 포함) }\end{array}$} & 전자지역정보화 사업 타당성 조사 & 10.8 \\
\hline & E-PORT 시스템 구축 타당성 조사 & 10.8 \\
\hline 한국수출입은행 & 멀티미디어 센터 건립 & $2,500.0$ \\
\hline \multirow{3}{*}{$\begin{array}{c}\text { 문화관광부 } \\
\text { (구 정보통신부 포함) }\end{array}$} & 국제 IT정책 및 기술 프로그램 & 30.0 \\
\hline & 한국인터넷 봉사단 & 6.9 \\
\hline & 국제대학원 IT장학사업 & 90.7 \\
\hline \multirow{3}{*}{$\begin{array}{c}\text { 교육과학기술부 } \\
\text { (구 교육인적자원부 포함) }\end{array}$} & APEC 사이버 교육협력 & 2.0 \\
\hline & APEC e-러닝 연수 프로그램 & 5.1 \\
\hline & ICT 국제교류 & 1.8 \\
\hline 여성가족부 & APEC 여성 IT 능력 제고 & 1.2 \\
\hline
\end{tabular}

자료 : 감사원, 2011

현재 ICT 인프라 확충을 위한 ODA 사업은 대체로 정부기관 및 연구기관의 정보망 구축이나 정보 센터 구축 등과 같은 프로젝트 형태로 이루어지고 있다. 인프라가 ICT 기술능력 제고의 근간이기는 하지만, 그 자체만으로는 실질적인 기술능력 발전으로 확장되기 어려움에도 대부분의 사업이 시스템 구축으로 끝나고 이를 지속적으로 이를 유지 - 발전시키기 위한 여타 사업과의 연계는 상당히 미흡한 수준이다. 또한 인프라 확충을 통한 ICT 기술능력 발전을 위해서는 초청연수 사업이나 인적 자원개 
발 사업과의 연계는 물론, 해당 협력국의 제도나 문화에 대한 포괄적인 이해를 바탕으로 지속적인 사 회적 과정으로 추진되어야 한다. 따라서 전반적으로 ICT 기술능력이 낮은 국가에서 ICT 센터를 구축 하고 나아가 이를 운영하기 위한 인력을 교육시킨다고 하더라도, 그들이 지속적으로 이를 관리할 수 있도록 협력국 정부와의 충분한 협의가 필요함에도 이를 간과하는 경우가 빈번했다.

아울러 초청연수사업의 경우에도 효과성을 높이려면 교육프로그램을 통해 연수생들의 실질적인 ICT 기술능력을 축적케 하고, 이것이 다시 협력국의 ICT 기술능력으로 확산될 수 있도록 다양한 연 계 사업들이 체계적인 하나의 틀 속에서 이루어져야 함에도 단기 연수 프로그램만 운영할 뿐 대학교 등 전문 교육기관에서 장기간 체재하면서 교육을 받는 프로그램은 운영하지 않고 있어 개도국의 ICT 인적자원 개발에 실질적으로 기여한다고 보기 어려운 실정이다. (권율 외, 2006)

\section{3. 협력국의 의지·협력 성공 사례}

원조는 공여국의 지원내용에 못지 않게 협력국의 태도에 의해 성과가 크게 달라진다. 자국의 발전 계획에 맞추어 원조를 최대한 활용하고 성장의 촉진제로 활용코자 하는 협력국에서는 ICT ODA사업 이 성공할 가능성이 높다.

라오스 전자정부구축 지원사업은 KOICA에서 2년(2004 2005년)간 95만 달러를 투입하여 라오스 의 수도인 비엔티엔에 전자정부센터를 개원하는 것이었다. 사업과정에서는 전문가 파견을 통해 기자 재 설치 및 교육이 충실히 이루어졌고, 전자정부 정책 및 시스템에 관한 자문을 통해 전자정부 정책 수립, 운영 전략, 입법 및 전자정부 시스템 구축 등에 대한 전자정부 실천계획의 토대를 마련해 주었 다. 이에 부응하여 라오스 정부는 적극적인 의지로 전자정부 실천계획을 수립하였고, ICT 관련 법안 (National Policy on ICT)을 제정하였다. 또한 동 사업진행 후 초청연수를 통해 교육을 받은 많은 공 무원들이 전자정부 정책 및 시스템에 대해 더 많이 이해하게 되었고, 그 후 라오스 자체 내 워크숍 등을 통해 전자정부에 대한 필요성과 가능성을 더욱 더 공유함으로써 사업 역량이 크게 강화되었다. 현재 라오스는 동 사업의 후속으로 중국 차관을 이용하여 전자정부를 위한 응용 프로그램과 주요 기 관 간 광케이블 연결 등 인프라 구축사업을 체계적으로 진행하고 있다.

두 번째 사례인 에콰도르 지방통신망 확충사업은 1995년 EDCF 승인 후 1996 2003년간 약 15백 만달러를 투입하여 수도인 끼또(Quito) 등 전국 주요지역에 전자교환기 및 부대시설을 설치하는 사 업으로서, 현대화된 교환설비를 제공하여 통신서비스의 질적 향상 및 사용자의 만족도 제고에 목적 이 있었다. 1994 년 자료에 의하면 에콰도르의 100 인당 전화보급률은 5.8 대(선진국은 유 - 무선 각각 50 대 수준)에 불과하고 보급된 전화도 전체인구의 $28 \%$ 가 거주하고 있는 Quito시 및 Guayaquil 시에 전체의 $60 \%$ 가 밀집되어 있는 실정이었다.

동 사업은 '농촌지역 대상 57 천회선 전전자 교환기 공급'의 일환으로 에콰도르의 경제개발 및 통 신개발정책에 부합하고 개발우선순위가 매우 높은 사업이었다. 동 사업이후 100 명당 전화보급율이 
1994년 5.8대에서 2004년 12.7대로 크게 증가하였고 기술지원도 성공적으로 이루어져 현지 기술자 들이 기본적인 수리 · 보수 등을 자체 해결하고 있는 것으로 확인되었다. 또한 자체 유지 · 보수 관리 를 위한 정부예산도 충분히 확보되어 지속가능성이 매우 높은 것으로 나타났다.

\section{V. 시사점 및 개선방안}

\section{1. 국내적 측면}

\section{1) 추진체계}

$\mathrm{ICT}$ 부문 $\mathrm{ODA}$ 의 효과성 · 효율성을 높이기 위해서는 중복 해소 - 연계 강화를 위한 현 추진체계 재 정비와 정부 주도에서 벗어나 민간 - 국제기구 등과의 파트너십 강화 등 추진체계의 외연 확장이 필 요하다.

먼저 사업 중복·연계 미흡을 최소화하기 위해서는 우선 정부기관 내에서 컨트롤타워에 의한 중복 - 연계성 검토 - 조정과 ICT 중점지원국가의 선정이 우선적으로 이루어져야 한다. 현재 총리가 위원장 인 국제개발협력위원회와 국무총리실의 ODA담당조직이 조정역할을 담당하고 있지만 ODA분야가 광 범위하여 ICT부문 ODA 컨트롤타워 역할을 하기에는 충분치 못하다. 따라서 동 위원회 산하에 ICT부 문을 전담하는 소위원회 구성 등을 검토할 필요가 있다. 이 소위원회에서 전체 ODA 국가전략 하에 중장기적 시각의 $\mathrm{ICT} \mathrm{ODA} \mathrm{전략을} \mathrm{마련하고,} \mathrm{이} \mathrm{전략} \mathrm{하에서} \mathrm{ICT} \mathrm{중점지원국가를} \mathrm{선정하는} \mathrm{것이} \mathrm{필}$ 요하다.

$\mathrm{ICT}$ 부문 $\mathrm{ODA}$ 는 기술 - 제도적 요소간 횡적 연계성이 강하고 통합적 시각이 요구되므로 특히 민간 부문과의 파트너십 형성이 중요하다. 이를 위해 먼저 ICT ODA사업에 관한 정보를 민간기업에게 최 대한 많이 제공하고 $\mathrm{ODA}$ 사업에의 참여 인센티브를 제공하여 이들 기업과 함께 ICT 지원사업을 추진 할 필요가 있다. 이 과정에서 해당기업들은 ICT기술력에 대한 협력국의 신뢰를 얻고 현지화 전략을 사전에 수행함으로써 미래의 잠재적 시장을 확보할 수 있다. 나아가 국내 시민단체, NGO, 교육 및 연구기관과의 개발협력 커뮤니티를 형성하여 상호간의 전문인력, 정보, 지식, 자원 등을 공유함으로 써 원조효과성을 제고시킬 필요가 있다.

아울러 ITU, WB, ADB, UNDP 등 국제기구와의 네트워크 및 파트너십을 강화하여 ICT 활용 개발 사업 지식과 노하우를 공유하고 개도국 사업에 공동참여할 필요가 있다. 이를 통해 ICT ODA의 효과 성 · 효율성을 증진시킬 수 있을 뿐만 아니라 ICT 전문인력의 국제화에도 도움이 될 수 있고, 협력국 의 ICT 관련 정보 획득에도 효과적이다. 


\section{2) 추진전략}

민 · 관 파트너십을 토대로 '선택과 집중'에 따른 중장기 ICT ODA전략을 정립해야 한다. 오늘날 ICT부문 경쟁은 '표준 전쟁'이라고 불릴 만큼 표준을 중심으로 전개되고 있다. 즉 자국의 국가표준이 나 자국 기업의 표준을 세계 표준으로 만들어, 세계 시장을 그 표준기술에 묶인(locked-in) 시장으로 만들어 지속적이고 독점적인 지위를 유지한다는 전략이다. 일단 한 표준에 묶이면 높은 전환비용 (switching costs)으로 다른 표준기술로 옮겨 가기가 쉽지 않기 때문에 아주 효과적인 시장지배 전략 으로 간주되고 있다. 그러나 어디에서나 실시되는 단발성 사업으로는 표준 선점이라는 목표를 달성 할 수 없다. 따라서 협력국의 수요와 시장 현황, 발전 가능성과 한국의 표준 기술 등을 전략적으로 고려하여 '선택과 집중'의 원칙하에 표준 전략과 유기적으로 연관되는 ICT ODA 사업을 수행해야 한 다. 하나의 예로, 한 지역을 선정해 가용 자원을 이 지역에 집중하면서 기반 설비(infrastructure), 물적 자원, 인적자원개발 및 교육, 활용 등에 모두 한국의 기술을 동원해서 개발하는 대규모 사업을 고려할 수 있다.

이상과 같은 포괄적 접근을 통해 '기반부터 단말(infra to terminal)'까지 인적- 물적 토대를 모두 제공하는 프로그램을 수행할 수 있다. 이 과정에서 대규모의 자원이 필요하고, 이를 동원하기 위해서 는 민간부문, 특히 기업과 공공부문의 파트너십이 필수적이고, 이를 통해 민 - 관 연대가 더욱 강화될 수 있다. 이렇게 모든 기술 및 교육을 우리나라의 기술 표준으로 설정해 놓으면 이 지역은 경로종속, 높은 전환비용 등 표준의 여러 효과들로 인해 향후 우리 ICT 기업들이 상대적으로 진출하기 쉬운 여 건을 갖게 된다. 한 지역에서 성공 사례를 만들면 다른 나라, 다른 지역에 이런 사업을 진행할 수 있 고, 결국 표준의 지역적 확산을 가져올 수 있다. 또한 이런 대형 사업의 성공 사례는 한국 ICT ODA 사업의 국제적 지명도를 높이는 데 기여할 수 있다.

\section{2. 협력국 측면}

ICT부문 ODA는 공여국의 경험에서 창출된 지식을 협력국의 상황에 적용하여 ICT 활용을 극대화 하는 지식기반 활동이며, 협력국의 특수한 개발환경을 충분히 이해하고 이에 적합한 개발지식을 전 하는 일이다. 따라서 공여국인 우리 입장의 일방적인 고려가 아니라 파트너십의 틀 속에서 협력국의 수요를 충분히 고려한 ODA가 되어야 한다. 협력국의 입장에서는 ICT ODA에서 얻어진 지식, 인적 · 물적 지원을 최대한 활용하여 국가 발전에 도움이 되도록 해야 한다. 이를 위해서는 협력국의 ICT 국 가발전계획과 수요에 부합하는 ODA가 제공되어야 하고 협력국이 ownership을 갖고 ODA를 활용할 수 있는 역량구축이 이루어져야 한다. 
〈표 9〉ICT부문 ODA의 공여국 중심과 협력국 중심 패러다임 비교

\begin{tabular}{l|l}
\hline \multicolumn{1}{c|}{ 공여국 중심의 기존 패러다임 } & \multicolumn{1}{c}{ 협력국 중심의 새로운 패러다임 } \\
\hline 원조국의 필요와 공급 기반 & 수혜국의 요구와 능력 기반 \\
\hline 기술로의 접근성 제공 & 지식으로의 접근성 제공 \\
\hline 접근성이 센터에 집중됨 & 접근성이 공간적으로 분산될 수 있음 \\
\hline 센터에 위치한 새로운 기술에 기반하여 접근성 제공 & 타 소스를 이용하여 인터넷상의 정보를 간접적으로 \\
(예 : 컴퓨터) & 현지인에 제공 (예 : 라디오) \\
\hline 컴퓨터와 같은 신기술의 수입에 전적으로 의지 & 원조과정의 단계에 따라 구기술과 신기술을 결합함 \\
\hline
\end{tabular}

자료 : 조정문, 2007, 재구성

그러나 협력국 중심의 패러다임으로 원조가 이루어진다고 해도 유의할 점이 있다. 개도국인 협력 국의 경우 정교한 행정시스템과 정당한 거너번스의 미구축으로 인해 자신들의 원조 수요에 관한 정 확한 정보 제공에 문제가 있을 수 있다. 이러한 문제를 해소하기 위해서는 협력국 내부의 정보에 일 방적으로 의존하기보다는 보다 신뢰성 있는 외국 원조기관이나 국제기구 또는 해당 협력국에서 활동 경험이 있는 외국 전문가들과의 교류를 통해 보완할 필요가 있다. 또한 협력국의 정보기술능력 축적 정도가 낮기 때문에 최첨단의 기자재 및 설비의 활용도가 낮을 수 있는데, 이러한 문제에 대비하여 협력국의 ICT 분야 기술 및 응용분야의 정확한 실태파악도 필요하다.

\section{3. 기술능력 단계별 지원 측면}

지금까지는 협력국 선정 및 ICT부문 ODA사업의 선정과정에서 정보기술능력은 충분한 고려의 대 상이 되지 못했다. 그러나 개도국의 ICT의 활용이라는 측면에서 보면 정보기술을 활용할 수 있는 기 술능력이 무엇보다도 중요한 고려 요소가 되어야 한다. 기술능력 수준을 고려하지 않는 ICT ODA는 한국의 ICT기술을 해외에 홍보하는 수준 이상의 효과를 기대하기 어렵다. 기술능력의 분류는 협력국 의 체계적인 기술능력 축적을 위해서 뿐만 아니라 공여국의 입장에서도 효과적인 ICT ODA 전략을 위한 원조방식과 원조내용의 차별화를 위해서도 반드시 필요하다. 원조 방식에 있어서는 기술 수준 이 낮은 ICT 초기단계 협력국의 경우 자체적인 IT 관련 서비스 및 제품을 제공할 수 있는 능력을 갖 추지 못하였으므로 무상 원조와 ICT 마스터플랜 수립 등 제도 구축지원 사업을 실시할 필요가 있으 며, 다음 단계로 ICT 기본정책은 있으나 인프라가 미흡한 협력국에게는 현지의 기초적 역량이 활용 개발될 수 있도록 정부통신망 구축사업 - ICT 인력양성 등 인프라 구축사업을 실시할 필요가 있고, 마지막으로 ICT 정부정책 및 정보통신 인프라가 갖추어진 협력국에게는 전자조달 - 전자통관시스템 등 전자정부 구축사업을 실시할 필요가 있다. 한편 원조의 내용에 있어서는 기술능력이 낮을수록 하 
드웨어, 즉 접근성 확보를 위한 인프라 지원에 비중을 두며, 반면 기술능력이 높을수록 소프트웨어 지원에 비중을 둘 필요가 있다.

협력국의 기술능력 향상을 위한 차별적 지원과 협력은 협력국의 수용능력이 고려됨으로써 ICT $\mathrm{ODA}$ 의 실질적 성과와 만족도를 높이는 효과적인 전략이 될 수 있다. 이러한 단계적 지원에 따른 기 술능력의 향상은 곧 더 많은 ICT 수요로 이어지게 되고, 그에 따라 한국 ICT산업의 협력국 진출 가 능성도 높아질 것으로 예상된다.

\section{VI. 결 론}

우리나라는 세계적으로 유례를 찾아보기 어려운 ODA 성공모델이다. 한국전쟁의 폐허 속에서 외국 의 유 - 무상 원조를 종자돈 삼아 절대적 빈곤을 탈출하고 한강의 기적을 일궈냈다. 이제 받은 것을 되갚아야 할 때이다. 세계화 - 정보화 시대에 개도국들은 ICT도입과 활용을 필요로 하고 있다. 이러 한 상황에서 ICT강국이라는 국가브랜드를 고양하고 국가간 정보격차 해소에 기여할 수 있는 ICT $\mathrm{ODA}$ 사업은 의미가 크다. 그러나 ICT부문 ODA사업의 효과성을 높이기 위해서는 '선택과 집중'이 중 요하다. 중장기적 $\mathrm{ICT} \mathrm{ODA} \mathrm{추진} \mathrm{전략하에} \mathrm{협력국을} \mathrm{선정하고} \mathrm{민} \mathrm{·} \mathrm{관} \mathrm{파트너십,} \mathrm{관계기관의} \mathrm{유기적}$ 인 협력의 바탕 위에 ICT ODA 사업을 추진해야 한다. 그리고 ICT가 협력국의 발전에 기여하기 위해 서는 협력국의 ICT 수요현황과 기술능력 및 발전능력을 고려하여 차별적인 ICT ODA가 이루어져야 한다.

이렇게 체계적이고 전략적인 ICT ODA의 실행 과정에서 협력국 내부에 ICT 시장이 만들어지면, 자연스럽게 우리 기업들이 시장에 진출할 수 있는 기회가 늘어나 경제협력의 단계로 발돋움할 수 있 다. 나아가, 우리나라 ICT ODA의 지속성이 담보되고 이에 대한 협력국들의 만족도가 높아질 경우 선순환 구조를 형성함으로써, 새로운 시장 확보와 한국 ICT 산업활성화에 기여하는 부메랑 효과도 나타날 것이다. 이러한 중장기적인 상생(Win-Win)효과에 ICT ODA는 경제협력의 기폭제이자 촉매 제가 될 수 있을 것이라 기대한다. 


\section{참고문헌}

\section{1. 국내문헌}

한국국제협력단(2005).「개발사업 분야별 추진방향 I $\lrcorner$, 한국국제협력단

한국국제협력단 및 한성대 산학협력단 연구용역팀(2007). 「ICT분야 협력사업 평가」, 한국국제

협력단

한국국제협력단 및 조원권, 박정호(2005).「ICT 협력사업 추진전략」, 한국국제협력단 한국국제협력단 및 (주)한국전산감리원 연구용역팀(2008).「정보통신분야 4 개사업 위탁 평가

보고서 $\lrcorner$, 한국국제협력단

한국국제협력단 및 김장성(2008), 「한-필리핀 IT 훈련원 건립사업 사후평가 보고서 , 한국국제

협력단

감사원(2011).「공적개발원조(ODA) 추진실태」, 감사원

국무총리실 (2010).「국제개발협력 선진화 방안」, 국제개발협력위원회

권 율 외(2006)「우리나라 대외 원조정책의 선진화방안 : 국제개발협력 패러다임의 변화와 한국

$\mathrm{ODA}$ 의 개혁과제」, 대외경제정책연구원

권 율 외 (2008).「최근 국제사회 공적개발원조(ODA) 동향과 향후 전망」, 대외경제정책연구원 김석주(2010). 전자정부 추진과정에서 부처간 갈등분석」, 한국지역정보학회지 제 13 권 제 2 호,

한국지역 정보화학회

김은미 외 (2009).「한국 원조체계의 분절이 원조 효과성에 미치는 영향 및 개선방안」, 한국국제 협력단

박복영(2007).「국제비교를 통한 한국형 원조모형의 모색」, 경실련 ODA Watch 제2차 정책포럼 오정연(2006).「한국의 정보화 정책 발전과정 및 성과」, NCA 이슈리포트 제 7 호, 한국전산원 조정문(2007).「한국형 IT ODA 수행모형 수립방안」, 한국정보문화진흥원

한국개발전략연구소(2007). 「한국적 개발협력 프로그램 발전방안 연구」, 한국국제협력단 한국국제협력단 (2009).「국제개발협력의 이해」, 한울아카데미

한국정보화진흥원(2010)「정보화 ODA사업 평가지표 개발 및 발전방향 연구」, 한국정보화진흥원 


\section{2. 국외문헌}

Hall, E(1959). 「The Silent Language $\lrcorner$, Garden City, NY : Doubleday

Heeks, R(2002). 「Information Systems and Developing Countries : Failure, Success, and Local Improvisations $\lrcorner$, The Information Society. Vol.18

Liebenau, J. and J. Backhouse(1990). 「Understanding Information : An Introduction」, London : Macmillan

OECD/DAC(1991). 「Principles for Evaluation of Development Assistance $\lrcorner$, OECD

OECD/DAC(2009). 「DAC Special Review of the Republic of Korea's Development Co-operation」, OECD

OECD/DAC(2001). 「Is it ODA?」, OECD

Walsham, G., V. Symons and T. Waema(1990). 「Information Systems as Social Systems : Implications for Developing Countries」in S. Bhatnagar and N. Bjorn-Andersen, eds. Information Technology in Developing Countries. B.V. (North-Holland): Elsevier Science Publishers

OECD/DAC 홈페이지 http://www.oecd.org/department/0,2688,en_2649_33721_1_1_1_1_1,00.html KOICA 홈페이지 http://www.koica.go.kr

EDCF 홈페이지 http://www.edcfkorea.go.kr 